\title{
DOI: 10.7596/taksad.v6i4.1110
}

Citation: Zueva, E., Shalneva, T., \& Osovskiy, O. (2017). Genre Transformation of the Fairy Tale in Contemporary Russian Literature. Journal of History Culture and Art Research, 6(4), 436-442. doi:http://dx.doi.org/10.7596/taksad.v6i4.1110

\section{Genre Transformation of the Fairy Tale in Contemporary Russian Literature}

\author{
Ekaterina Zueva', Tatiana Vasilieva Shalneva ${ }^{2}$, Oleg Osovskiy ${ }^{3}$
}

\begin{abstract}
This research is devoted to some peculiarities of structure and semantics of contemporary Russian fairy tale. The analyzed genre model is quite actual in the literature of modern turn of the centuries. It is actualized in the creativity of L. Petrushevskaya, A. Kabakov, B. Akunin, M. Fray, D. Bykov, etc. This is connected with the universality of themes and problems and the dynamics of structure of genre analyzed. Modern literature process suggests the use of various genre forms (including fairy-tale one) in the context of realization of game strategies of world construction with the deconstruction principle domination. The usage of the most productive for such kind of research methods (structural-semantical and comparative ones) gives grounds for understanding the specifics of realization of deconstruction principle through the variety of forms and meanings. For example, the scheme of "genre memory" is widely used in contemporary fairy tale. If that scheme deals with the sphere of semantics, then structural components are actively deconstructed (e.g. fairy tales by L. Petrushevskaya). If the meaningful fairy tale composition models are actualized, then the semantic component is widely transformed (e.g. Moscow Fairy Tales by A. Kabakov). The most important peculiarity of contemporary fairy tale is the integration of fairy tale, legendary, mythological and literary plots to the one game system. The result of this is on the one hand travestying of the iconic plots, on the other hand achieving the new meanings due to including context mechanisms.
\end{abstract}

Keywords: Game strategy, Deconstruction, Intertextuality, Situation model, Travestying.

\footnotetext{
${ }^{1}$ Kazan Federal University.

${ }^{2}$ Kazan Federal University.

${ }^{3}$ Mordovia State University.
} 


\section{Introduction}

Appeal to the fairy tale genre model is quite relevant for Russian literature of the new turn of the centuries. This is primarily due to the presence of ethical certainty there that, in the modern situation of the "washed out" semantic boundaries turns to be a significant factor of the authors' sustained interest in this genre. An appeal to the genre of fairy tale by contemporary Russian writers is also determined by the tradition of its use in Russian literature for symbolic generalization and comprehension of the problems of modern reality.

Also, the fairytale structure has clearly expressed features of the plot, chronotopic, archetypal levels, which allows to use components in the process of game transformation of the genre model of the fairy tale. The most important feature of the modern fairy tale is the integration of marked cultural plots (fabulous, mythological, legendary, religious, literary) into a single game space. Thus, the sphere of concepts of pieces of literature is deepened and expanded through variability (as a method of transforming forms and transcribing meanings).

A fairly active appeal of contemporary writers to the genre of the fairy tale is determined by the appearance of numerous works of modern scholars connected with the study of this genre (the works of M. Lipovetsky, 1992; L. Ovchinnikova, 2001; M. Polyakov, 1983; E. Neelova, 1987; A. Bobyleva and T. Prokhorova, 2016; and others). They turn to various aspects of genesis, structural and semantic originality, the specific functioning of the genre model of a literary fairy tale in the context of contemporary literature, relying on the fundamental research of predecessors (in particular, V. Propp, 2001).

\section{Materials and Methods}

Appeal to the study of contemporary Russian fairy tales (in particular, in the works of L. Petrushevskaya and A. Kabakov) reveals the existence of the principle of deconstruction of the traditional genre form, which is realized through the usage of the game strategy of the world-modeling by the authors. This strategy is manifested through the actualization of intertextual links, the transformation of images and situations of the traditional genre model, etc. It allows us to identify the specifics of the implementation of the principle of deconstruction through the variability of meanings and forms.

The terms "deconstruction" and "intertextuality" are the basic concepts of the theory of postmodernism, which determines the methodology of this research, which, first of all, consists of the works of scholars who developed the basic postmodernist theories (R. Barthes 1964, 1973; J. Kristeva, 1969; J. Lacan, 1966; J. Lyotard, 1984; and others). Also, as a methodological basis, we use works on the theory of literature, which are related to the study 
of the structure and philosophy of the literary text (Yu. Lotman, 1994; V. Rudnev (1996), V. Amineva, 2014, 2017; and others)

The most relevant methods for this research are structurally-semantic and comparative. The structural and semantic method allows us to analyze various algorithms and proportions of the semantic and form-building components of the modern fairy tale, and the comparative method makes it possible to identify the correlation of "pre-plots" with their interpretations in the modern fairy tale, and also helps to determine the specifics of the author's genre variants analyzed.

\section{Results and Discussion}

The works of L. Petrushevskaya and A. Kabakov can be named the bright examples of modern literary fairy tale.

A distinctive feature of most of the tales of L. Petrushevskaya (except for specific "linguistic" tales) is accentuated intertextuality. Thus, images of W. Hauff's fairy tale Little Longnose are used in the fairy tale Girl Nose; images of fairy-tales Thumbelina and Ugly Duckling by H. K. Andersen - Mother-Cabbage, Small and Even Less, Dus'ka and Ugly Duckling. The fairy tale The Prince with Golden Hair includes variations of the plot elements and individual characters of the fairy tales of A. Pushkin (The Tale of Saltan Tsar, etc). Kind of "communicative dialogue as a method of variation" (Makhnina \& Shustova, 2015) is created through all these means.

The transformation of images is carried out through the replacement or exclusion of their individual structural and semantic components. Thus, in the fairy tale Girl Nose, method is used of replacement the hero's age and gender specificity is used, as well as change the semantics of the heroine's image as a "victim of circumstances" (Nina initially has an ugly nose, and the sorcerer makes her nose beautiful and elegant according to her request). The image of the protagonist of the fairy tale Dus'ka and Ugly Duckling is correlated with the "prototype" (the image of the ugly duckling) psychologically (the ability to sacrifice himself, modesty, etc.), but in the tale there is no motif of transformation ("ugly duckling" in the fairy tale of L. Petrushevskaya is an elderly drake and, of course, he does not become a beautiful swan). L. Petrushevskaya also uses "reduced", parodic versions of images. For example, the image of the fragile, tender Thumbelina from the eponymous fairy tale by H. K. Andersen is transformed in the fairy tale Small and Even Less to the image of Thumbelina awkward and capricious, and is replaced by the image of a thick Kapochka in the fairy tale MotherCabbage. 
Recognizable fairy-tale situations can be met in the creativity of L. Petrushevskaya (for example, envious sisters doom the younger sister to all kinds of misadventures in The Prince with Golden Hair, the sorceress helps a childless woman to become a mother in MotherCabbage, etc.), but more often situational models undergo transformation. One of the ways of transformation is the substitution of the structural components of the "pre-plot" situations for the opposite (the fairy tale Nina Komarova uses a plot of a very well-known fairy tale GusiLebedi (Geese-Swans), but with significant changes (she herself, not her brother is the main charachter, the culprit of the separation of the girl from her relatives is not Baba-Yaga, but the married couple who adopted Nina). L. Petrushevskaya extends the situational model by incorporating new characters into it (for example, the image of a swan Dus'ka in the fairy tale Dus'ka and Ugly Duckling, the image of the boy rescuing Thumbelina in the tale Small and Even Less). Another way to vary the situational model is the inclusion of the social everyday realities of modern reality. So, in the tale Two Sisters traditional fairy-tale plot of rejuvenation unfolds in the context of the gloomy post-Soviet reality (poor sisters are forced to drink overdue medications, which become miraculous "magic" substance giving youth in the story).

Using a variety of forms of structural deconstruction, L. Petrushevskaya always preserves the traditional genre model in the semantic sense. The peculiarity of L. Petrushevskaya's fairy tales is the presence of traditionally good finals. Thus the writer actualizes the "memory of the genre", protects its semantic core from destruction.

The vivid example of transformation of the fabulous models in contemporary literature is the cycle Moscow Fairy Tales by A. Kabakov. The title is defined by the attribute of all plots of the cycle (Moscow). The Moscow Fairy Tales by A. Kabakov represent a synthesis of the mythological, legendary, fairy-tale, literary stories that have been rethought in the chronotope of modern times, but are firmly entrenched in the culturological tradition (for example, the myth of Prometheus is played out in the chapter The Fire of Heaven, the myth of Icarus - in the chapter The Rising Stream, episodes of religious semantics are structured in the chapters Project Babikon (construction of the Tower of Babel), Wanderer (punishment of Agasphere), a fairy tale about Red Riding Hood can be found in the Red and Gray, the chapter From the Life of the Dead uses the plot about Sleeping Beauty, etc.). Among all game techniques of plot transformation the most widely used technique seems to be the inclusion of certain semantic components in the chronotope of modern Moscow. The result of the implementation of this technique becomes a travestying of well-known images, characters, situations, etc. Thus, the image of the Tower of Babel is transformed to a long-term building, Prometheus, who gave fire to people - to the image of a fairly tipsy writer who unexpectedly found himself in the role of an electrician, the image of Don Juan - to the image of an ordinary "womanizer". 
Sometimes recognizable plots are included to the coordinates of modern reality without changing ethical certainty, but more often, preserving the structure of a fairy tale, the author deconstructs its semantics.

For example, fairy tale Love is Evil, structurally correlated with the tale The Frog Princess, is being constructed in the same way. Its hero is the modern "Ivan the Fool" (lieutenant-colonel Igor Kapets, demobilized as a result of a severe wound to the head while serving in Afghanistan). Brave, animal-loving (this feature is especially emphasized in the "pre-plot"), lonely, humble the hero accidentally finds his love as "the princess-frog", inverted by his admiration and devotion to the human hypostasis (zoomorphic and anthropomorphic components organically coexist in the image of beloved of the hero in his mind, at times significantly away from reality). The next stage in the development of the plot is the departure of the princess-frog: according to the hero, the special services of the overseas country ("semantic synonym" is Kashchei Bessmertny) take the beautiful princess, who is forced to leave Russia and bids farewell to her knight in an interview that is broadcast on television ... This is how the magic story of love in the life of Afghanistan hero ends, and with it his life itself in the coordinates of reality. He, according to the plot of the famous fairy tale, intends to meet again with his beloved, so he goes on a trip to the "other" world. As you can see, the structure of the fairy tale Love is Evil is correlated with the tale The Frog Princess, but the semantic core of the folk tale is completely deformed: in the modern world, even the best human qualities cannot help the hero not only to become happy, but simply to survive.

Another example of such deconstruction is the fairy tale Red and Gray. The plot of the new fairy tale is identical to the known one: some girl in a red cap ("Little Red Riding Hood") goes to visit an elderly sick woman ("grandmother"), says about it to the man in gray ("Gray Wolf"), who is ahead of her, binds her grandmother, tries to rob, etc. The "Little Red Riding Hood" calls for professional security guards ("hunters") who kill Gray (details of this episode (the subsequent burning of a corpse), reflect the terrible realities of Russia during the 90s).

Images of Gray and "grandmother" in the semantic plan actualize the fairy-tale "prototypes" (cruelty and cunning / naivety and gullibility). Only the image of Red Riding Hood is transformed (she works in the Tube), that's why Lyudmila Ostretsova wears red cap. "Grandmother" becomes a person without a certain place of residence, because she gives her flat as a present and "Little Red Riding Hood" realizes her dream of a beautiful metropolitan life. 


\section{Conclusion}

Thus, after considering the tales of L. Petrushevskaya and A. Kabakov, we can note that in both cases writers turn to well-established subjects, character images, chronotopic models and other semantic and structural components common for the genre of a literary fairy tale. These components are included in a single game system, in the context of which their semantic and structural recoding occurs. In both cases deconstruction techniques are widely used. For L. Petrushevskaya's fairy tales, the use of deconstruction as applied to the genre and compositional parameters of the fairy tale with the predominant preservation of the semantic "memory of the genre" is a characteristic feature. For the work of A. Kabakov, on the contrary, it is more important to emphasize the stable formal components of the genre with a significant transformation of the semantic level.

Summarizing the material presented, we can conclude that the genre of the fairy tale is promising in the modern literature, because, on the one hand, the block of fairy-tale texts potentially applicable to game strategies is extremely wide (it can include folklore, literary fairy tales in a wide range of temporal and spatial coordinates). On the other hand, the logic of genre development is definitely connected with the processes of synthesis of a fairy tale with other genres (for example, fantasy, mystical or social prose, fable genre and others). This process (partly revealed in the above works) seems to us an important form of modeling and functioning of a literary fairy tale in the foreseeable chronological perspective.

\section{Conflict of interests}

The authors confirm that the data do not contain any conflict of interests.

\section{Acknowledgements}

The work is performed according to the Russian Government Program of Competitive Growth of Kazan Federal University.

\section{References}

Amineva, V. R. (2017). Symbolization as a way of art completion in the story by A. Eniki "Unvoiced testament". XLinguae Journal, 10(1), 12-24.

Amineva, V. R. (2014). "Universal" and "Unique" as the Categories of Comparative Literature. Middle East Journal of Scientific Research, 20(12), 2094-2098. 
Barthes, R. (1964). Essais critiques. P.: Seuil.

Barthes, R. (1973). Le Plaisir du texte. P.: Seuil.

Bobileva, A. \& Prokhorova, T. (2016). The interaction between the theatrical and fairytale discourses of Yuri Buida's novel "Blue blood". Journal of Language and Literature, ISSN. 2078-0303, 7(3), 206-210.

Kristeva, J. (1969). Recherches pour une semanalyse. P.: Seuil.

Lacan, J. (1966). Ecrits. P.: Seuil.

Lipovetsky, M. N. (1992). Poetics of a literary tale (based on Russian literature of 19201980's). Sverdlovsk.

Lotman, Yu. M. (1994) Lotman and the Tartu-Moscow semiotics school. M.

Lyotard, J. F. (1984). Le difterand. P.

Makhnina, N. G. \& Shustova, E. V. (2015). Literary reception of Jr. R. R. Tolkien works in the Russian fantasy of the XX-XXI centuries: Variations stage. Social Sciences (Pakistan), 10, 951-955.

Neelov, E. M. (1987). A fairy tale, a fantasy, the present. Petrozavodsk.

Ovchinnikova, L. V. (2001). Russian literary fairy tale of the XX century (History, classification, poetics): the author's abstract. Dissertation for Doctor of Philology: 10.01.01, 10.01.09. Moscow.

Polyakov, M. (1983). In the world of ideas and images. Historical poetics and theory of genres. $\mathrm{M}$.

Propp, V. Ya. (2001). Morphology of the fairy tale. M.

Rudnev, V. (1996). Morphology of reality: A study on the philosophy of the text. Moscow: Russian Phenomenological Society. 